\title{
DIMMABLE STREET LIGHTING APPLICATION USING A MICROCONTROLLER
}

\author{
Alper Turan Erguzel, Ahmet Karaca, Abdullah Ferikoglu, Zafer Demir
}

Original scientific paper

This article describes an energy saving system of road lighting suited for different lighting scenarios. The designed system is applied in a university campus for a 12 -month period with a resulting 24,1\% electric energy saving. Within the system high pressure sodium (HPS) lamps are dimmed by programmed microcontroller cards at desired rates according to calendar and clock data in a 12-month period using a designed interface. In addition to energy saving, the designed system allows a remote accessed power analyzer to be used to follow up consumed energy data for the lighted area.

Keywords: dimmable lighting system; dimmable street lighting systems; lighting control systems; road lighting

\section{Primjena prigušene ulične rasvjete pomoću mikroregulatora}

Izvorni znanstveni članak

U radu se opisuje sustav uštede enrgije kod ulične rasvjete za različite vrste rasvjete. Taj se sustav primijenjivao u sveučilišnom kampusu u trajanju od 12 mjeseci uz uštedu električne energije od $24,1 \%$. U tom su sustavu u periodu od 12 mjeseci svjetiljke s natrijem pod visokim pritiskom prigušene pomoću kartica programiranog mikroregulatora u odgovarajućim rasponima u skladu s kalendarskim i vremenskim podacima primjenom dizajniranog sučelja. Uz uštedu energije, taj sustav omogućuje primjenu daljinskog analizatora energije u praćenju podataka o potrošenoj energiji u osvijetljenom području.

Ključne riječi: prigušeni sustav rasvjete; sustavi prigušene ulične rasvjete; sustavi za reguliranje rasvjete; ulična rasvjeta

\section{Introduction}

According to electricity consumption data obtained from the Statistical Institute of Turkey, 2,1 \% of the $186,100 \mathrm{GWh}$ energy produced in the year of 2011 by Turkey Electricity Distribution Inc. was consumed for partial street road lighting. This means that $3908,1 \mathrm{GWh}$ of energy was consumed for this aim [1].

To give overseas examples, there are approximately 2,28 million street lighting lamps in Australia, while $33 \%$ of them are located on the main roads, $67 \%$ are on local roads. The annual energy cost of public lighting in Australia has exceeded $\$ 125$ million (and more than $\$ 250$ million including maintenance) [2].

In the Netherlands, the dynamic roadway lighting was traced to the energy crisis of the 1970's and to save energy, some luminaries were turned off. As a result of that, there was an increase in accidents. Since 1995, the Netherlands has installed and operated a dynamically lighted roadway with High-pressure sodium lamp that can be adjusted at three lighting levels (low, normal and high) depending on the amount of traffic. This system has resulted in a reduction of traffic accidents [3].

The studies in 1972 and 1994 which were about two major road safety showed that lighted roads were safer than unlighted roads $[4,5]$. Besides, Transport and Public Works Department in the Netherlands tested the concepts of reduced luminance during low traffic hours and under good metrological conditions. As a result of the test, it was concluded that dynamic public lighting would be appropriate and the same result was also supported by the European Standards. Additionally, when luminance levels were reduced below $50 \%$ level under favourable conditions, it was observed that $30 \div 40 \%$ of energy savings were achieved and the service life of the lamps was extended due to using the proper lamps [6]. Another study was undertaken by the Optometry and Neuroscience Department of the University of Manchester Institute of Science and Technology into ocular stress while driving at night. Measurements performed on the M65 in Lancashire UK under different lighting levels, provided important results about the relationship between ocular stress and motorway lighting. According to the results, reducing lighting with dynamic dimming resulted in a decrease in ocular stress and risk of accidents [7].

In road lighting, road safety, lighting pollution and energy savings are among the important key factors which should be considered because there are rising concerns about the adverse impacts of high brightness in road lighting, especially in Europe and China. The overuse of high brightness in road lighting may cause a road safety problem, energy wastage and light pollution. Increasing light pollution is believed to have negative effects on health and environment such as the sleep disorders and abnormal hormonal changes of human beings, plant and wildlife distortion [8].

The use of traditional lighting system in a footpath running alongside the River Thames in England had negative effects on different species of wildlife including bats. With dimming, the system provides $80 \%$ energy savings by dimming luminaries at $10 \%$ level when the road is being used less, and by increasing this level up to $100 \%$ when there are heavy pedestrian crossing times. In addition to this, with this system alongside the River the light leaking from the path to the native wildlife would be prevented by about $50 \%$ [9]. In a study conducted by the University of Manchester in England, it was observed that with the use of dimmable lamps the comfort of drivers and road safety increased while the rate of accidents and driver stress diminished [10].Today, many street lamps have been saving energy with mid-night lights strategies. Among them, the latest used internationally is "Smart Street Lighting Energy-Saving Control". This latest generation street lighting systems have been offering great advantages such as a high degree of information exchange, long-term use, less maintenance needs and costs [11]. 
Also the paper [12] covers data for a campus lighting (National Center for Scientific Research), where energy saving was achieved through dimming from 18:00 $\div 22: 00$.

As a result, considering the global energy shortage, the importance of energy saving in outdoor lighting is increasing with each passing day. Street lighting consisting of HPS lamps and dimmable electronic ballasts will be the technology of the future.

In this experimental work, a road lighting system was designed and applied in a university campus for a 12 month period. A 24,1 \% electric energy saving was achieved compared to classical photocell on-off lighting system .The project connected to this article entitled "the Campus Lighting Automation", with number 2012-09-00001, was supported and funded by the Commission of Sakarya University, Turkey, Scientific Research Projects.

\section{The test road characteristic}

The selected sample road for testing the lighting control system is in Sakarya University Esentepe Campus area. It is on the starting point of service vehicles, vans and city buses, and it is busy at any time of day. The number 2 ring road allocated for measurements by Sakarya University Administration was a two-way road, two-lane for each direction.

The location selected for setting the lighting automation system was at the entry point of the University Dormitories being used heavily by pedestrians. Also, there were no parasitic light sources affecting the light measurements.

Road lighting was ensured by armatures with $150 \mathrm{~W}$ HPS vapour lamps on top of 9 meter high poles with 2 consoles, one for each way. The road width for each way was 7 meters and the distance between the poles was $40 \mathrm{~m}$. The road was of R1 type and had a homogeneous structure. The pole-armature distance was $1,5 \mathrm{~m}$ and the armature was placed at an angle of 15 degrees above the horizon. The lamps used had $15000 \mathrm{Lm}$ Luminous flux and $2000 \mathrm{~K}$ Colour Temperature. The ballast was a 150 $\mathrm{W}$ electronic ballast allowing lamp power control with a $0 \div 10 \mathrm{~V} \mathrm{DC}$, conforming to CE standards. Fig. 1 below illustrates the overall layout of the system.

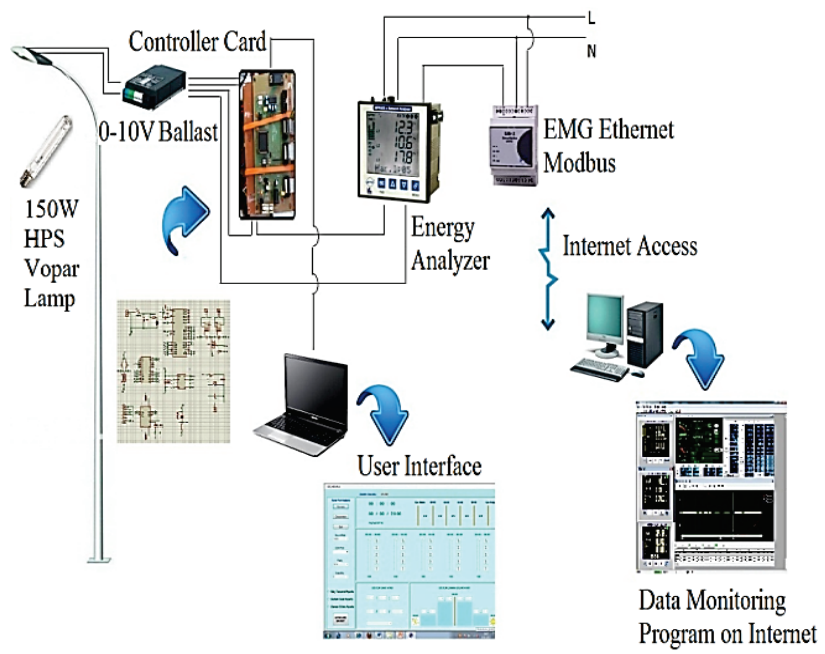

Figure 1 Lighting control system general setup

\section{Material and methods}

The experimental work of lighting control depends on replacing already used line voltage with $220 \mathrm{~V}$ photocell operated magnetic ballasts with electronic ballasts, allowing lamp power control with $0 \div 10 \mathrm{~V} \mathrm{DC}$ voltage. The control of sample ballast was realized with a designed microcontroller card. An energy analyzer and internet access were also included in the system as in Fig. 1.

\subsection{Lighting control system}

Today, the lighting automation systems have two basic control methods: control by a communication cable and automatic control. The advantage of the former is its ability to control most parameters, including time, against its disadvantage of high centralized control and setup costs. The latter has the advantages of low cost, easy installation and simple maintenance but it is not as flexible as the control by communication cable method $[13,14]$.

The control scheme of this experimental work is based on the principle of turning on/off and dimming the lamp power by the electronic ballast operated on a $0 \div 10$ DC voltage, thus adjusting the power consumption of the lamp. This $0 \div 10 \mathrm{~V}$ DC voltage is provided by lighting control card over a DAC. The lamp power data of time is transmitted to the control card via a computer connected to the lighting control card.

The power of lamp is adjusted to the desired level at determined time range depending on these data. In order to follow up the performance of the system an energy analyzer remotely accessible via Ethernet is connected to the system. The system's performance is evaluated according to power consumption data of the lamp by an interwired energy analyzer (ENTES) via internet. The microcontroller connection is illustrated below in Fig. 2.

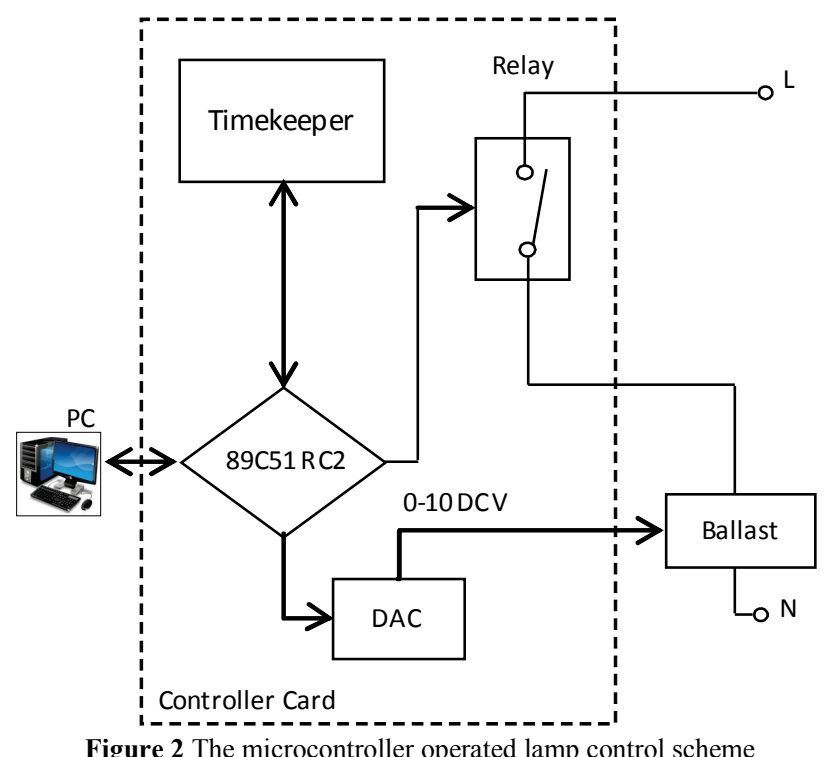

The 89C51RC2 microcontroller used on the lighting control card is produced by ATMEL firm. With the designed program loaded into the microcontroller, the ballast according the lamp power can be adjusted to the 
desired level. M48T08 integrated timekeeper is utilized to determine the time. This has a non-volatile integrated memory preventing data loss when power is cut off. Also there are a calendar and clock integrated within this, providing real-time calendar and clock values.

The calendar and clock related power values are kept integrated in NVRAM. The 89C51RC2 first reads calendar and clock values from the timekeeper and obtains related lamp power values from the program records and then sends the corresponding digital control data to the DAC integrated.
DAC0808 integrated has 8-bit resolution, thus separating $0 \div 10 \mathrm{~V}$ range into 255 pieces with $39,21 \mathrm{mV}$ intervals included in the system as in Fig. 1.

\subsection{User Interface}

Lighting control board communicates with a dedicated computer using RS232 communication protocol. The required lamp operation scenarios are transferred to control card with the help of interface in the computer.

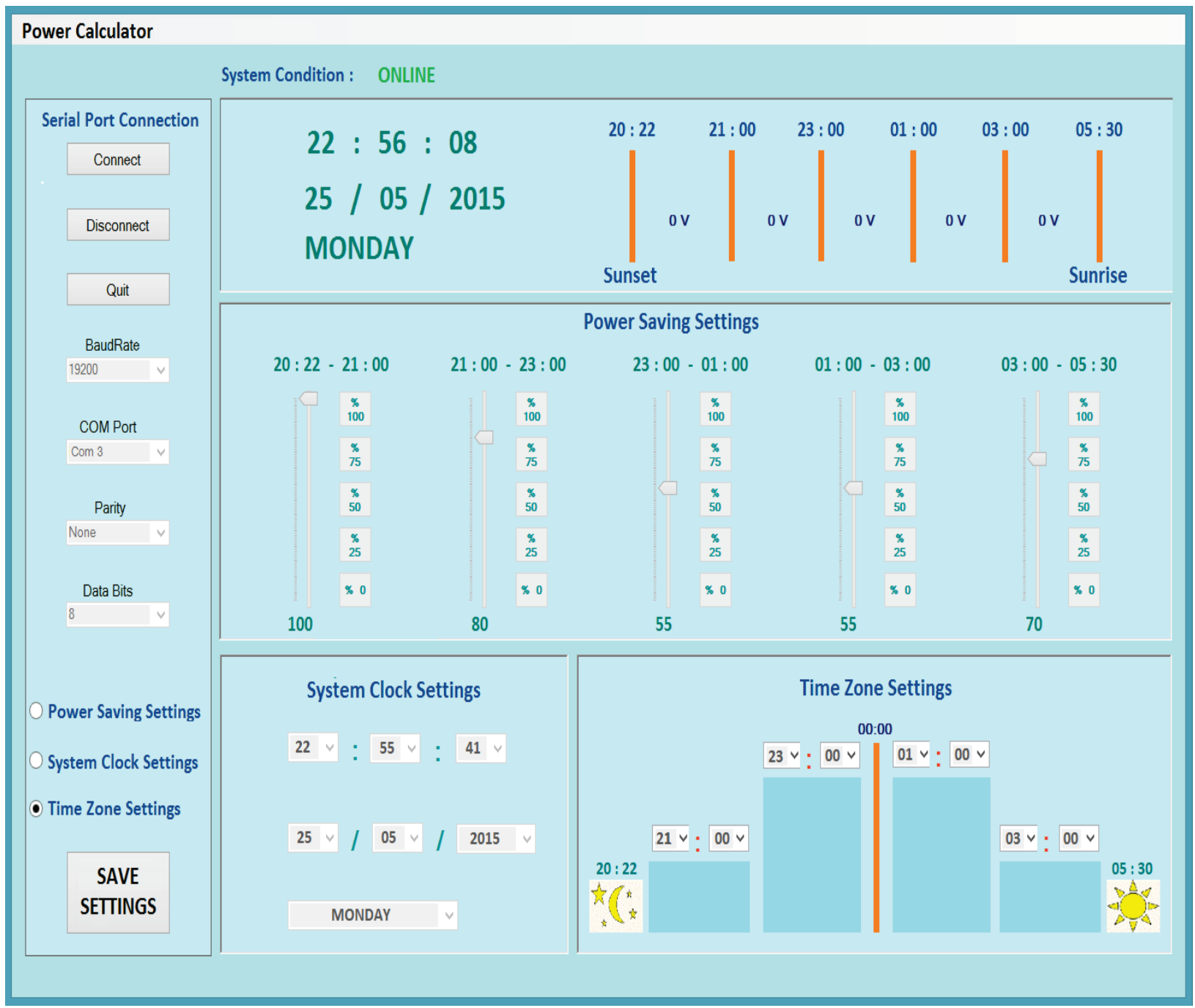

Figure 3 Lighting control card interface

In Fig. 3, connect button on the serial port connection section is linked to the lighting control card. When connected to the card, the system conditioning status is roster from online to offline status and it indicates that the interface is ready to intervene in the system. When connecting the lighting control card with the connect button, the date and time information is shown on the interface.

The lamp power is adjustable between $55 \%$ and 100 $\%$, with the aid of "Power Saving Settings" button on the program's interface. The calendar and clock data on the lighting control card is monitored and changeable by the option of "System Clock Settings" located on the interface.
The "connect button" provides connection with the card by returning "system condition" from "offline" to "online". In this case, when the connection is established, the reports of clock, calendar, the hours of sunrise and sunset are read from timekeeper and are displayed on the interface.

The connection settings between lighting control card and user interface can be made by "Serial Port Connection" section. The lighting control card and user interface provide the sufficient data transfer rate.

For this reason, 19200 baud rate was preferred. The time from sunset till sunrise is divided into five parts and the run time of these parts is adjusted by the "Time Zone Settings". 


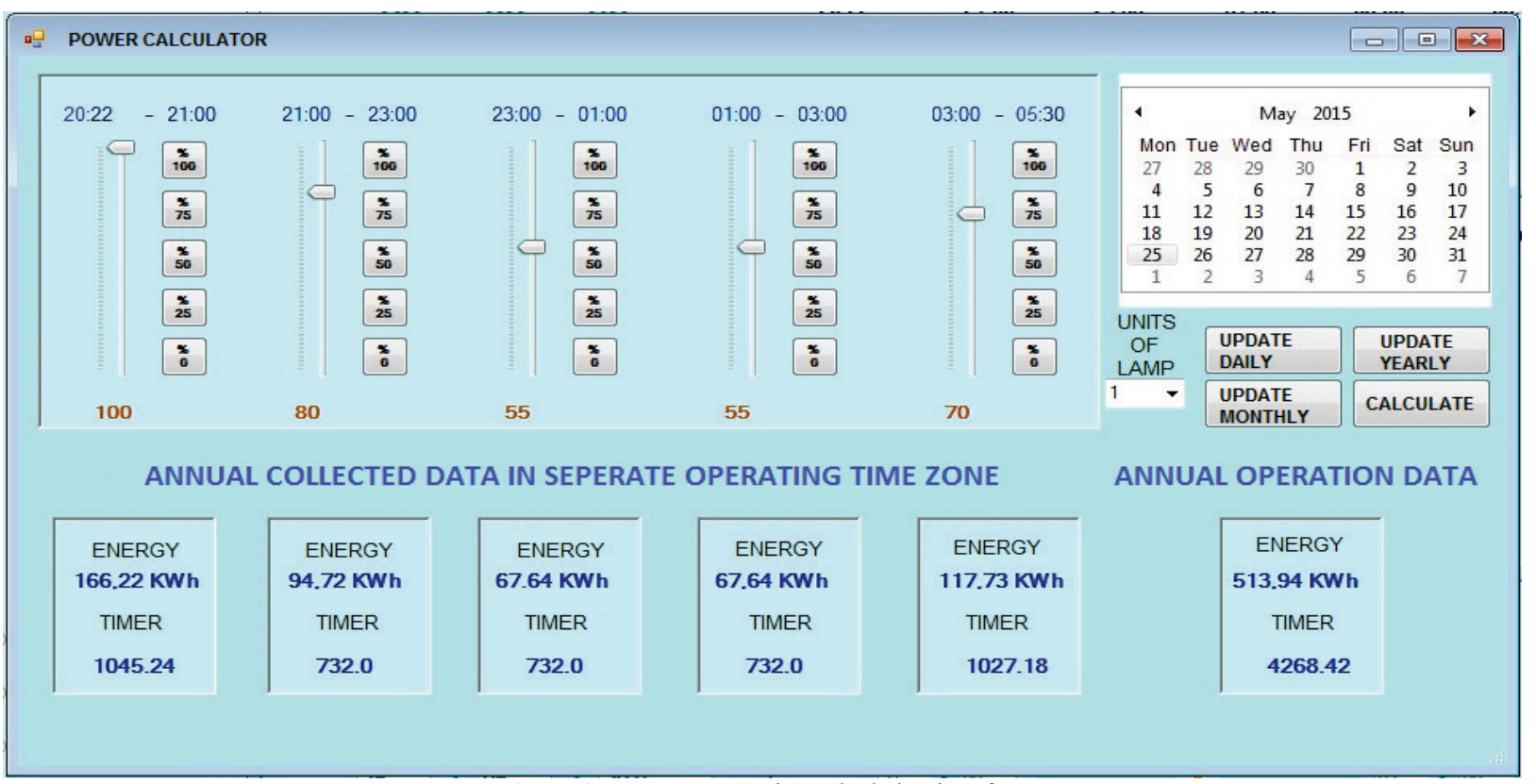

Figure 4 Power consumption calculation interface

On the interface between the red bars on the right side of current calendar and time the $0 \div 10 \mathrm{~V}$ DC voltages applying to ballast for dimming can also be seen as a snapshot.

After all changes, to validate the settings, changes are transferred to lighting control card by pressing the "Save Setting" button in the lower left corner of the interface. The connection with the card can be disconnected by "Disconnect" button and "Quit" button can be used to exit from the program interface.

Fig. 4 shows that a menu is added to the interface showing how much energy will be consumed as a result of implementing scenarios when the power button is pressed.

In addition to this, with the aid of "Power Calculator" menu inserted to interface of the program, the energy consumption corresponding to the selected scenario is estimated taking into account the sunrise and sunset times with a one-year period in the system. Besides, the "Annual Collected Data in Separate operating Time Zone" table in the interface menu shows in which time intervals how much total time (hours) the lamp works within a year. In addition the total energy and total operating times are calculated and shown on the "Annual Operation Data" section. The designed lighting system was applied with an electronic ballast HPS lamp and results were monitored over a one-year period, Jan. 2013 $\div$ Jan. 2014. Tab. 1 below provides the observed consumed and saved energy data over the one-year period.

Table 1 Observed electric energy data for the designed lighting system

\begin{tabular}{|c|c|c|c|c|c|c|c|}
\hline Months & $\begin{array}{c}\text { Daily } \\
\text { Average } \\
\text { Consumed } \\
\text { Energy / kW·h }\end{array}$ & $\begin{array}{c}\text { Daily } \\
\text { Average } \\
\text { Saved Energy } \\
/ \mathrm{kW} \cdot \mathrm{h}\end{array}$ & $\begin{array}{c}\text { Monthly } \\
\text { Average } \\
\text { Consumed } \\
\text { Energy / \% }\end{array}$ & $\begin{array}{c}\text { Monthly } \\
\text { Average } \\
\text { Saved Energy } \\
/ \%\end{array}$ & $\begin{array}{c}\text { Monthly Total } \\
\text { Consumed } \\
\text { Energy / } \mathrm{kW} \cdot \mathrm{h}\end{array}$ & $\begin{array}{c}\text { Monthly Total } \\
\text { Saved Energy } \\
\mathrm{kW} \cdot \mathrm{h}\end{array}$ & $\begin{array}{c}\text { Monthly Total } \\
\text { Consumed Energy } \\
\text { Without } \\
\text { Lighting Control } \\
\text { System / } \mathrm{kW} \cdot \mathrm{h}\end{array}$ \\
\hline Jan & 1,77 & 0,50 & 77,75 & 22,25 & 54,93 & 15,81 & 70,66 \\
\hline Feb & 1,62 & 0,49 & 76,64 & 23,36 & 47,02 & 14,33 & 61,35 \\
\hline Mar & 1,45 & 0,45 & 75.99 & 24,01 & 44,95 & 14,22 & 59,17 \\
\hline Apr & 1,26 & 0,42 & 75,04 & 24,96 & 38,07 & 12,67 & 50,74 \\
\hline May & 1,11 & 0,39 & 73,80 & 26,20 & 34,50 & 12,21 & 46,71 \\
\hline Jun & 1,02 & 0,38 & 72,85 & 27,15 & 30,83 & 11,50 & 42,33 \\
\hline Jul & 1,06 & 0,39 & 72,98 & 27,02 & 32,93 & 12,19 & 45,12 \\
\hline Aug & 1,20 & 0,41 & 74,36 & 25,64 & 37,23 & 12,83 & 50,06 \\
\hline Sep & 1,27 & 0,39 & 76,45 & 23,54 & 38,11 & 11,75 & 49,86 \\
\hline Oct & 1,57 & 0,45 & 77,46 & 22.54 & 48,93 & 14,24 & 63,17 \\
\hline Nov & 1,74 & 0,48 & 78,26 & 21,74 & 52,29 & 14,54 & 66,83 \\
\hline Dec & 1,82 & 0,50 & 78,22 & 21,78 & 56,47 & 15,72 & \\
\hline
\end{tabular}

The operating range of used lamp was identified as between sunset and sunrise. In addition the dimming level is set at the lowest level in the first operation and shutdown time. Dimming adjustment is realized for the Sunset $\div 21: 00,21: 00 \div 23: 00,23: 00 \div 01: 00,01: 00 \div$
03:00, 03:00 $\div$ Sunrise time intervals. These scenarios considered traffic density of vehicles which is depicted in Fig. 5.

The importance of safe and controlled outdoor lighting in the busy hours of traffic is better understood. 
According to Article: 28720 of "General Lighting Design, dated 27 July 2013, in Official Gazette of the Republic of Turkey", the use and savings of lighting in any way belong to the university that is responsible for the plant operation [15].

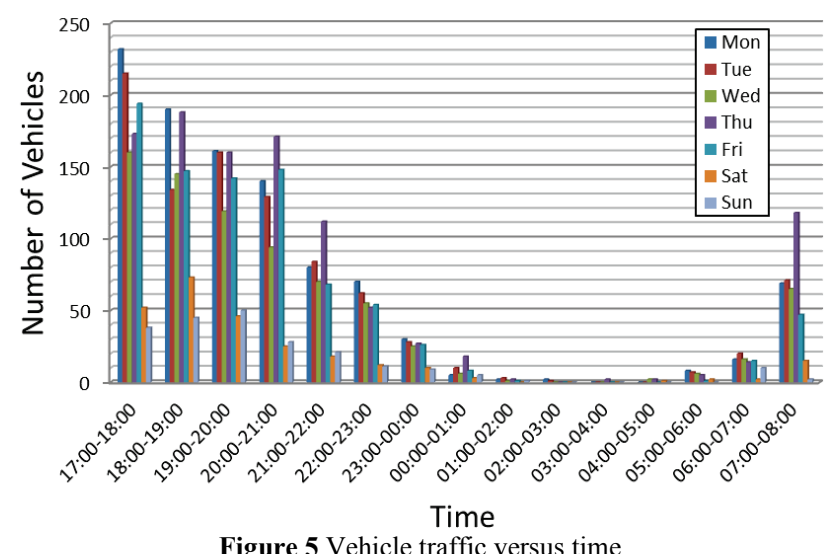

Figure 5 Vehicle traffic versus time

Again, in respect of the relevant article of the Official Gazette, lighting levels can be reduced 50\% after 02:00 at night. Also, according to Article 3c, to reduce the lighting level, dimmable luminaries that have "dim" feature and are dimmable in accordance with remote control and automation can be selected.

Today in Europe and China, there are rising concerns about the usage of high brightness in road lighting which may cause the road safety problem, energy wastage [16, $7,17]$ and light pollution [18, 19]. In a study which is implemented under the reference of European Community, a great amount of energy savings is obtained by $100 \mathrm{~W}$ decrease in $150 \mathrm{~W}$ HPS lamps without losing comfort [20].

From April 2009, in England, due to good safety records and low levels of night time traffic, the Highways Agency has turned off lighting after midnight for five hours on sections of the M4 and M5 in order to cut energy use and carbon dioxide production [21].

\section{Results and conclusions}

The lamp was at full power (100\% level) in the range of Sunset $\div 21: 00$, the busiest hours for the pedestrian and vehicle traffic. It was reduced to $80 \%$ level between $21: 00 \div 23: 00$. The lamps operated at 55\% level in the range of 23:00 $\div 01: 00$ and 01:00 03:00, and at 70\% level between $03: 00 \div$ Sunrise.

The system consumed $516,26 \mathrm{~kW} \cdot \mathrm{h}$ in total during the observed time span. The energy saving achieved was $161,93 \mathrm{~kW} \cdot \mathrm{h}$ compared to the on/off (without dimming) lamp operation.

The average saving percentage was $24,1 \%$. Fig. 6 gives saving percentage versus months. The primary considerations are comfort and safety while dimming in the lighting scenario. When dimming level increased for the purpose of saving, it is predicted that saving will be obtained in further high level.

The use of dimmable systems would be inevitable due to rapidly depleting energy sources and rising emission of greenhouse gasses.

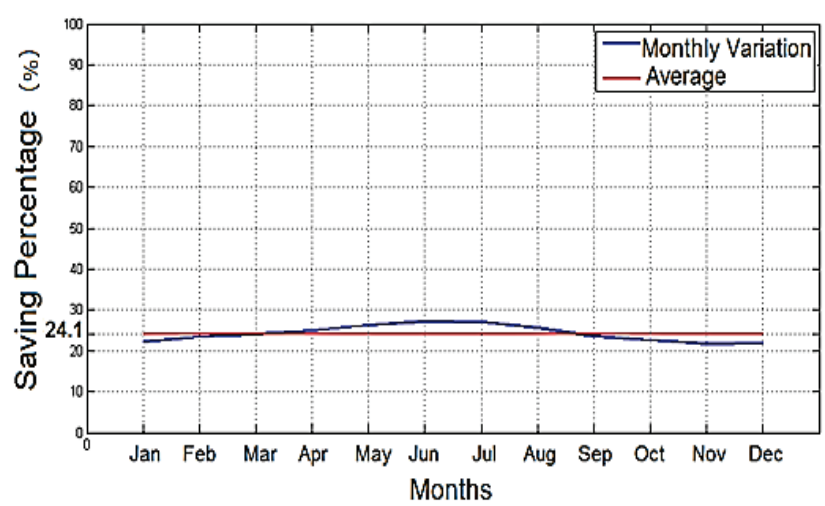

Figure 6 Monthly variation and average energy saving percentage of the designed system

The potential saving to be made from the lighting energy is an important factor to decrease $\mathrm{CO}_{2}$ emission from electricity consumption. Reduction in $\mathrm{CO}_{2}$ emission has changed with respect to energy savings. The emission production for Turkey's grid circuit is calculated by taking into account the type of power plants, fuel type, amount of electricity production and date of entry. The emission factor obtained as a result of this calculation is called combined margin. According to Bureau Veritas, the Organization of Neutral Certification, the combined margin emission factor for Turkey obtained by TEIAS data was found to be $0,58 \mathrm{t} \mathrm{CO}_{2} / \mathrm{MW} \cdot \mathrm{h}$ of energy saved through the system [22], [23].

The $\mathrm{CO}_{2}$ emission is provided by energy savings of a lamb.

Annual $\mathrm{CO}_{2}$ Emission = Annual Energy Consumption $\times$ Combined Margin Factor (4.1)

Annual Energy Consumption $=0,16314 \mathrm{MW} \cdot \mathrm{h}$

Combined Margin Factor $=0,58$

Annual $\mathrm{CO}_{2}$ Emission $=0,095$ tons

If the saving was not achieved, $\mathrm{CO}_{2}$ emission would be 0,095 tons. It can be obtained from the formula of (4.1). If this has been practiced by 389 armatures in campus area, it can be inferred $\mathrm{CO}_{2}$ emission that has decreased 36,53 tons. This amount of $\mathrm{CO}_{2}$ emission affects global warming in an unfavourable way and may cause serious health problems to the public. It is known that excess light affects wildlife. Besides that, the damage of wildlife which is caused by light pollution is minimized by using dimmable lights [24, 25].

\section{References}

[1] TUIK, "Electricity Distribution and Consumption Statistics of Turkey", 2011, Ankara, Turkey.

[2] Australian and New Zealand Governments, "Street Lighting Strategy", July 2011.

[3] Wilken, D.; Lutkevich, P. J.; Arens, J.; Ananthanarayanan, B.; Watson, P.; Havard, J.; Hasson, P.; Burkett, K.; Unick, J. European Road Lighting Technologies. p: 41, 2001.

[4] Box, P. C. Freeway accidents and illumination. // Highway research record 416 / Highway Research Board, 1972.

[5] Griffith, M. S. Comparison of the safety of lighting options on urban freeways. // Federal Highway Administration Online report, US Department of Transport, Autumn 1994 vol. 58 , No. 2.

[6] Baenziger, T. D. Management of public lighting. / European Council for an Energy Efficient Economy Right Light. 5, May 2002, Nice, France. 
[7] Collins, A.; Thurrell, T.; Pink, R.; Feather, J. Dynamic dimming: The future of Motorway lighting. // The Lighting Journal, Sept/Oct. 2002, pp. 25-33.

[8] Chung, H. S. H.; Ho, N. M.; Hui, S. Y. R.; Mai, W. Z. Case Study of a Highly-Reliable Dimmable Road Lighting System with Intelligent Remote Control Power Electronics and Applications, European Conference, 2005.

[9] "Why the dimmer way is smarter for street lighting", http://www.lighting.co.uk/know-how/why-the-dimmerway-is-smarter-for-street-lighting/8626645.article (accessed 28.05.2015)

[10] Elvik, R. Meta-analysis of Evaluations of Public Lighting As Accident Countermeasure. // Transp. Res. Rec., No. 1485, pp. 112-123, 1995.

[11] Van Tichelen, P.; Weyen, D.; Geens, R. et al. A Novel Dimmable Electronic Ballast for Street Lighting with HPS Lamps. In IEEE IAS 00 (October 2000: Rom, Italy). Conference Record of the 2000 IEEE Industry Applications Society Conference. Rom, 2000, pp. 3419-3422. https://doi.org/10.1109/ias.2000.882657

[12] Zotos, N.; Stergiopoulos, C.; Anastasopoulos, K.; Bogdos, G.; Pallis, E.; Skianis, C. Case Study of a Dimmable Outdoor Lighting System with Intelligent Management and Remote Control. // 2012 International Conference on Telecommunications and Multimedia (TEMU). 2012, pp. 43-48. https://doi.org/10.1109/TEMU.2012.6294730

[13] Venkata Lakshmi, O.; Nageswarao Naik, B.; Rajeyyagiri, Sivaram. The Development of Road Lighting Intelligent Control System Based on Wireless Network Control. // International Journal of Science and Applied Information Technology. 1, 4(2012), pp. 113-116.

[14] Guixi, J.; Baoyue, G. Control System of City Electrical Lighting Based on Radio Paging Network. // Journal, Chinese Journal of Scientific Instrument. 23, 5(2002), pp. 103-105.

[15] Official Gazette of the Republic of Turkey, Issue no 28720 was published on 27 July 2013

[16] Simpson, R. Lighting control: technology and applications, Focal Press, 2003

[17] Kaptein, N. A.; Hogema, J. H.; Folles, E. Dynamic public lighting (DYNO). // The $8^{\text {th }}$ European Lighting Conference Lux Europa 1997, Paper 461.

[18] Hoek, K. T. V. Dutch Approach To Energy Efficient Street Lighting. // The $8^{\text {th }}$ European Lighting Conference Lux Europa 1997, Paper 439.

[19] Huiqian, X. The harm, Tendency and Prevention of Light Contamination. // Illumination Technology and Management. 1(2003), pp. 1-8.

[20] Ruscassié, R.; Rouffet, J. B.; Huber, M.; Maechler, E.; Rast, U.; Zissis, G.; Glaize, C. NumeLiTe: An Energy Efficient Lighting System for Roadways and a Commercial Application of a Dimming Power Supply. // Industry Applications Conference, 2004. $39^{\text {th }}$ IAS Annual Meeting. Conference Record of the 2004 IEEE, Vol. 2. https://doi.org/10.1109/ias.2004.1348593

[21] "Motorway Lighting to be switched off", The ENDS Report, Issue 411, April 2009, page 24.

[22] http://www.project-climate.de/wp-content/uploads/2011/11/ Verifizierungsreport_Geothermie_Tuerkei.pdf (accessed 28.05.2014)

[23] TEIAS (Turkish Electricity Transmission Company), 2011 Energy Statistics, Ankara, 2011.

[24] Official Gazette of the Republic of Turkey, Issue no 28720 was published on 27 July 2013

[25] Bennie, J.; Duffy, J. P.; Davies, T. W.; Correa-Cano, M. E.; Gaston, K. J. Global Trends in Exposure to Light Pollution in Natural Terrestrial Ecosystems. // Remote Sense. 7, (2015), pp. 2715-2730. https://doi.org/10.3390/rs70302715

\section{Authors' addresses}

Alper Turan Erguzel

Sakarya University

Department of Electrical and Electronic Engineering

M-6 Block Esentepe Campus,

54187 Serdivan Sakarya/Turkey

Tel +90264 2956454

aerguzell@sakarya.edu.tr

\section{Ahmet Karaca}

Sakarya University

Department of Electrical and Electronic Engineering M-6 Block Esentepe Campus,

54187 Serdivan Sakarya/Turkey

$\mathrm{Tel}+902642955454$

akaraca@sakarya.edu.tr

\section{Abdullah Ferikoglu}

Sakarya University

Department of Electrical and Electronic Engineering

M-6 Block Esentepe Campus,

54187 Serdivan Sakarya/Turkey

Tel +90264 2955454

af@sakarya.edu.tr

\section{Zafer Demir}

Anadolu University

Department of Electronics Technology

Iki Eylul Campus, 26555 Eskisehir/Turkey

Tel +90222 $2241389 / 5147$

zaferdemir@anadolu.edu.tr 